\title{
Relationship of Self Concept, Problem Solving and Self Adjustment in Youth
}

\author{
Harwanti Noviandari ${ }^{1, a *}$, Agus Mursidi2,b \\ ${ }^{1}$ Department of Guidance and Counseling, University PGRI of Banyuwangi, East Java, Indonesia \\ 2Department of History Education, Faculty of Teachers Training and Education, University PGRI Banyuwangi, East Java, Indosesia \\ a hnoviandari83@gmail.com, b agusmursidi78@gmail.com \\ ${ }^{*}$ Corresponding Author \\ Whatsapp number: [+62-82334660992]
}

How to Cite : Noviandari, H., \& Mursidi, A. (2019). Relationship of Self Concept, Problem Solving and Self Adjustment in Youth. International Journal for Educational and Vocational Studies, 1 (6), 651-657

\section{ARTICLE HISTORY}

Received: 11 July 2019

Revised: 21 August 2019

Accepted: 22 September 2019

\section{KEYWORDS}

Relationship;

Self-Concept;

Problem Solving;

\section{ABSTRACT}

This study aims to find a relationship between self-concept and problem solving with adapting to adolescents. The research subjects were 138 teenagers in class VII of SMP Negeri 3 Banyuwangi. Data collection is done by using the scale of self-concept, problem solving scale and scale of adjustment in adolescents that are compiled by researchers themselves. These three scales use a Likert model consisting of 5 alternative answers. Data were analyzed using regression analysis. The results of the study show (1) There is a significant relationship between self-concept and problem solving with adjustment variables in adolescents; (2) There is a very significant positive relationship between self-concept and adjustment in adolescents; and (3) There is a very significant positive relationship between problem solving and adjustment in adolescents. Effective contributions from self-concept variables and problem solving together have an effect of $40.5 \%$ on adapting to adolescents, so there are $59.5 \%$ of other variables that influence adolescents' adaptation in addition to the two $\mathrm{X}$ variables studied.

This is an open access article under the CC-BY-SA license.

\section{INTRODUCTION}

Adolescence is a transition period (transition) from child to adult, where the period is a tumultuous period and time to seek self-identity. Teenagers try to find their identity faced with demands to be able to adjust to change, both changes that occur in physical conditions, ways of thinking, emotions and social interaction. Teenagers as social beings are also equired to be able to interact with other people, so that all their lives are required toto be ableadjust because life always changes.

The process of adapting to a new environment is not always easy for teenagers, especially in early adolescence. Like teenagers who are in aenvironment new schoolthat have different characteristics from the previous school. For example, grade VII students of junior high school (SMP) are the initial classes where students come from elementary schools. According to Suryani, et al. (2016) which states that students at the junior high school level are at a level of development called adolescence. During this period, adolescents experience a transition period for the first time from childhood to adulthood. In high school, students meet friends, teachers, subjects and environment a new to make students, in this case the teenager must be able to adjust to be able to complete his education. The inability of adolescents in the process of adjusting to the new environment can lead to various main problems in their social interactions. This has the potential to cause problems in her, including low self-adjustment problems, including problems with adjustment to teachers, friends, subjects and the environment. As a result, children do not want to go to school, do not want to learn, like to play truant, dare to fight the teacher and in the end the achievement learning decreases (Subagyo, 2013).

Based on the observations and interviews of researchers with tutors at SMP Negeri 3 Banyuwangi, it was revealed that there were some teenagers who claimed that the many tasks that needed to be done made teenagers feel depressed and time their was limited to doing assignments, plus demands from parents to take lessons outside school hours, studying and attending extracurricular activities at school. This was supported by reports from several subject teachers who said that there were a number of teenagers who looked sleepy when the 
lesson took place, did not complete the task, decreased learning achievement in the even semester, attended the first lesson but skipped the lesson next.

The results of the observations and fleeting interviews show that not all adolescents succeed or are able to adjust themselves in their environment. This is supported by various news or reviews regarding problems and behavior of devianta doles cents found in several media, both print and media electronic caused by the inability of adolescents in the process of adjustment adolescent. The use of drugs, fights between students, and free association are some forms of behavior maladjustment adolescent that show an inability to make adjustments to both themselves and their social environment. The fact shows that the majority (80\%) of drug users are adolescents aged 15-20 years, most of them (76\%) are junior, high school and vocational students. (Maharani \& Andayani, 2003). Fights among students, often called brawls, are also a form of behavior maladjustment adolescent that is increasingly increasing.

Not all teenagers, as students, are able to carry out self-adjustment tasks in their learning environment. This is evident from school cases such as violations of school rules, fights between students, teenagers who cannot work together or interact with friends, and so on (Maharani \& Andayani, 2003). Hurlock (1999) argues that self-adjustment is one of the developmental tasks most difficultin adolescence.

Adaptation made by adolescents in the new environment is an attempt to bring together the demands of oneself with the environment. One of the internal factors that influence individual adjustment is self-concept (Ahyani \& Kumalasari, 2012). Self-concept can determine whether or not the individual is easy to make adjustments and shows his existence in social life.

Various problems arise when adolescents are not able to harmonize demands originating from within themselves with the demands expected by their environment. Adolescents who fail to overcome problems often become insecure, school performance decreases, relationships with friends become less good and various problems and other conflicts that occur (Yuwono et al., 2006). The inability of adolescents to harmonize the demands that arise in themselves and the environment certainly can cause conflicts or problems that can affect the process of adapting to adolescents.

Success or failure of adolescents in overcoming stress and finding solutions to various problems depends on how adolescents use the experience gained from the environment and the ability to solve these problems can form a attitude more stable and more mature personal. Adolescents who fail to overcome problems often become insecure, school performance decreases, relationships with friends become less good and various problems and other conflicts that occur (Yuwono et al., 2006). The inability of adolescents to harmonize the demands that arise in themselves and the environment certainly can cause conflicts or problems that can affect the process of adapting to adolescents. From some of the above explanation raises questions about whether there is a relationship between self-concept and problem solving with adolescent adjustment. The question requires answers, so research needs to be done so that the questions that arise can be answered, supported by the facts found at the research site.

\section{LITERATURE REVIEW}

\subsection{Adolescent Adaptation}

Ali and Asrori (2006) state that adolescence is often known as the period of seeking self-identity, by Erickson called the term ego identity (ego identity). According to Monks et al. (2006) distinguish adolescence into four parts, namely pre-adolescence 10-12 years, early adolescence $12-15$ years, adolescence middle15-18 years, and late adolescence 18-21 years.

Adjustment in the original language is known as adjustment or personal adjustment. Adaptation according to Worchel and Goethals (2000) is a activity daily that involves yourself, the environment and people around you. Self-adjustment according to Schneiders (in Ali and Asrori, 2006), is a process that includes mental responses and behaviors that individuals fight for in order to succeed in facing internal needs, tension, frustration, conflicts experienced, and to produce quality harmony between demands from within individuals with the demands of the outside world or the environment in which individuals are located. Runyan and Haber (1984), put forward the characteristics ofself-adjustment effective, among others:

1. Appropriate perception of reality Differences in perception are influenced by the experiences of each person who is different from each other.

2. Ability to deal with stress and anxiety Having the ability to deal with stress and anxiety means that individuals are able to overcome problems that arise in life and are able to accept failures experienced.

3. Having a positivepositive self-image Aself-image is related to an individual's assessment of himself .

4. Ability to express good emotions The ability to express emotions well means that individuals have good emotional expression and emotional control.

5. Good interpersonal relationships Individuals who have good adaptation are able to form relationships in a quality and useful way.

According to Ali and Asrori (2006), there are a number of psychological factors that have a influence strong on the dynamics of adjustment, namely; Needs, are needs that are internal. Motivation, is an interpretation of the character and purpose of the individual response and its relationship with adjustment depends on concepts that explain the nature of motivation. Perception, through individual perceptions can determine how he should react 
to the stimulus that is around him because perception is a series of events that bridge certain stimulus and behavior.

Ability. The development of adolescent abilities consists of 3 aspects, namely: cognitive, affective and psychomotor. These three aspects can color the dynamics of Adolescent Self-Adjustment. Personality. Youth personality dynamics is very coloring the dynamics of adjustment so that adolescents can reach the stages of operational thinking formal (such as: interested in the opposite sex, building culture in groups, realizing the values contained in the norms of society and so on).

\subsection{Self-Concept Self}

Concept is a translation of self-concept and is closely related to individual personality because self-concept is an organized conceptual self and consistent which consists of perceptions about the characteristics of "self-subject" or "self-object" and perceptions of relationships between the subject and the self with other people with various aspects of life along with the values that attach to these perceptions. According to Brooks (in Rachmat, 2003) that self-concept is our views and feelings about ourselves, both physical, social and psychological that are obtained through experience from individual interactions with others.

The manifestation of self-concept is reflected in a person's reaction pattern, can be observed from reactions that tend to be permanent and underlying patterns of behavior. For example, someone who has an optimistic pattern of behavior, behavior that is not easy to give up and wants to try new and useful things is a reflection of a self-concept positive. Conversely, someone who considers himself less capable tends to be pessimistic, will behave in fear of facing new things and fear of being unsuccessful, and this is a reflection of a negative self-concept (Widodo, 2006).

Self-concept according to Santrock (2007) refers to the evaluation of certain fields of self . The concept of self has a considerable influence on individual behavior, that is individuals will behave in accordance with their own self-concept (Rachmat, 2012). The concept of self in this study is a construct regarding views, thoughts, feelings, one's judgment of himself, physically, psychologically, morally, cognitively and social relations which are formed and developed as long as the individual lives and interacts with the surrounding environment.

Hurlock (1999) in Muawanah, and Pratikto, (2012) stated that in general, adolescents have the six aspects of self-concept, namely:

1) The concept of the physical self is the image of teenagers yentang about his appearance, with his sex, the importance of the body in relation to the behavior, and prestigegiven his body in the eyes of others.

2) Psychic self concept is a picture of adolescents about their abilities and disabilities, their self-esteem and their relationships with others.
3) The concept of social self is a picture of teenagers about their relationship with others, with peers, with family, and others.

4) The concept of emotional self is a picture of adolescents about emotions themselves, such as the ability to resist emotions, angry, sad, or cheerful, vindictive, forgiving, and others.

5) The concept of self a spiration is a picture of teenagers about opinions and ideas, creativity and ideals.

6) Self-concept of achievement is a picture of adolescents about progress and success that will be achieved both in learning problems and life success.

There are various factors that influence the formation of self-concept according to Burns \& Fitts (in Zebua and Nurdjayadi, 2001), including: age, gender, physical condition and appreciation of the condition, treatment and attitudes of other people around him, meaningful experiences gained in relating with other people and the influence of meaningful figures in their lives. Self-concept is not permanent, but develops continuously along with the stages of individual development and the broader social interaction faced by the individual. Adolescents who are able to form positive self-concepts can adjust and accept input from the environment, whereas teenagers who develop negative self-concepts easily feel indecisive, pessimistic and withdraw from association.

\subsection{Problem Solving}

Anderson (in Suharnan, 2005) defines problem solving in terms of problem solving as an activity that relates to the choice of a way out or a suitable action and changing conditions (present state) to an expected situation (future state or desired goal)) Adolescents who have goodabilities problem solving will achievegoals the desired, namely teens can solve problems effectively and efficiently. Anderson (in Febri Hariyanti \& Suharnan, 2013) distinguishes two important aspects in solving problems, namely attitudes and actions of a person. Attitude aspects include; think positively about problems, think positively about problem solving and think systematically. Attitudes of positive thinking about problems such as being a problem seeker, looking for discomfort or gaps that exist in themselves and also other people, then ask yourself about what are the possible causes of discomfort or gap, then think of the risks associated with actions that being done and other alternatives and looking for what are the obstacles.

Positive thinking attitude towards problem solving, for example: seeing oneself as a person who is capable and able to solve problems, recognize the sources of strength that are in themselves and look for external sources that if possible can solve problems. The attitude of systematic thinking, for example at a certain stage in an effort to solve a problem, sometimes needs to pause and keep thinking, do not jump directly to conclusions, and plan step by step in solving a problem. Action aspects include; formulating problems, searching for and gatheringfacts 
important, finding ideas for problem solving, choosingideas the bestand implementing them. Actions to formulate a problem, for example: determine the scope of the problem, understand the subject matter, state clearly the current situation and the situation you want. The act of looking for and gathering facts, for example: determining the source of facts and obtainingfacts sufficientand thinking carefully about each fact collected.

There are several things that usually become obstacles in solving problems, namely: first is the mindset of someone who sees or resolves a problem only in a certain way so that it often becomes a barrier or has difficulty when having to solve new problems differently. Second is functional provisions (Functional Fixedness) is someone who views that an object can only be used based on past experience so that it is often difficult for individuals who are involved in solving new problems (Febrihariyanti \& Suharnan, 2013). The factors that can hinder an individual's ability to solve problems aremindset and functional determination.

\section{METHODS}

This research uses a quantitative approach with the subjects of the study are all. VII grade students in SMP Negeri X in the city of Banyuwangi, which amounted to 138 students divided into 5 classes. The sampling method in the study uses purposive sampling where sample selection is based on certain considerations namely class VII students are students who have just undergone a transition period from elementary school (SD) to junior high school (SMP), so that is the age entering the period early teens.

\section{The Variables and Research Instruments}

Item discrimination test and reliability test in this study were carried out on 103 respondents and analyzed with the help of the SPSS computer program (Statistical Product and Service Solution) version 21.0.Data collection methods used in this study, namely:scale self-adjustment, self-concept scale and problem solving scale with a Likert scale model consisting of 5 (five) levels of assessment, this refers to the opinion (Azwar, 2013) which says that the choice is being raised on the grounds that if the item is written correctly, variations in the answers will come out automatically.

Assessments in the adjustment scale range from very agree to strongly disagree. Aitem favorable score of 5 (five) indicates strongly agree, score 4 (four) indicates agree, score 3 (three) indicates unable to determine whether or not to agree or neutral, score 2 (two) indicates disagree and score 1 (one) indicates very disagree. Anitem unfavorable is 1 (one) to strongly agree, 2 (two) to agree, 3 (three) indicate unable to determine whether to agree or not or neutral, 4 (four) indicating disagree, 5 (five) indicating strongly disagree.

After the item validity test was carried out, there were 24 valid items that had the index corrected moving from 0,271 to 0,517 . The results of the reliability of self adjustment were indicated by Cronbach Alpha of 0,813 for 24 valid items. After the item validity test is carried out, based on the results of the validity calculation or discrimination on the self-concept item known from 56 items, there are 41 valid items.discrimination Items of self-concepthave a corrected index moving from 0, 263 to 0,650 . The results of self-concept reliability are shown by the reliability of Cronbach's Alpha of 0, 903.After the item validity test is done, based on the results of validity or discrimination the self-concept item is known from 56 items, there are 46 valid items that have a corrected index moving from 0,267 to 0,591 . The results of problemreliability are solvingindicated by the reliability of Cronbach Alpha of 0, 914.

\section{Hypothesis}

a. There is a relationship between self-concept and problem solving with adapting to adolescents.

b. There is a relationship between self-concept and adjustment in adolescents.

There is a relationship between problem solving and adapting to adolescents.

\section{RESULTS AND DISCUSSION}

\section{Results}

Data analysis techniques are conducted to test the relationship between self-concept and problem solving with self-adjustment is a two predictor regression analysis technique. Testing is done to determine the relationship of the whole variable, self-concept (X1) and problem solving (X2) with self-adjustment (Y). Based on the results of the statistical analysis with regression analysis the price coefficient $\mathrm{F}=45.181$ at $\mathrm{p}=0.000(\mathrm{p}<$ 0.01). This means that the first hypothesis in the study which reads "There isrelationship a significantbetween self-concept and problem solving with self-adjustment", canbenot accepted.

The results of regression analysis are also used to determine the relationship between each variable, self-concept (X1) with adolescent adjustment (Y) andrelationship problem solving (X2) with self-adjustment (Y). Based on the results of theanalysis regressionwhich shows the price $t=3.711$ at $p=0,000(p<$ 0.01 ). This means, partially the self-concept variable is positively related and very significant with self-adjustment, thus the second hypothesis in this study is accepted. Whereas, the relationship betweenvariables problem solving and self-adjustment is obtained by the price $t=3.373$ at $0.001(p<0.01)$. This means, partiallyvariables problem solving are positively related and very significant with self-adjustment, thus the third hypothesis in this study is accepted.

Price effective contribution of these two variables (X1 and $\mathrm{X} 2$ ) is a self-concept and problem solving with variable adjustment $(\mathrm{Y})$ indicated by $\mathrm{R}$ Square or the price 
of R2 of 0.405 which means that the variable self-concept and problem solving together give the effect of $40,5 \%$ of adjustment. This means that there are other variables of $59.5 \%$ which have an effect on self-adjustment not examined in this study.

Descriptive statistics also showed an adjustment (mean) value with the amount of data $(\mathrm{N}=138)$ was 91.1765 with a standard deviation of 8.94169 . The mean self concept with the amount of data $(\mathrm{N}=138)$ is 151.9632 with a standard deviation of 17.00824 . The average problem solving with the amount of data $(\mathrm{N}=138)$ is 167.9706 with a standard deviation of 16.48251 .

\section{Discussion}

Based on the results of the regression analysis the results obtained if together between self-concept and problem solving have a significant relationship with adjustment. This is indicated by the coefficient of $\mathrm{F}=45,171$. Based on the analysis, the study hypothesis of the first and reads "ada association asignificantbetween self-concept and problem solving dith adjustment" acceptable. These results are in accordance with the opinion of Desmita (2010) which explains that one's success in adjusting can be seen from emotional maturity, intellectual maturity, social maturity, and responsibility. That is, individuals who have self-concept and good problem solving can develop their abilities in adjusting to their surroundings.

Self-adjustment is a natural and dynamic process that aims to change individual behavior so that relationships are more in line with their environmental conditions (Fatimah, 2006). Individuals who have the ability to overcome problems that occur with good emotional control and have aimage positive self-are able to establish good interpersonal relationships with others (Ningrum, 2013). In line with qualitative research conducted by Ningrum (2013), studies on adolescents regarding parental divorce and adolescent adjustment. The results of his research show that the subject is able to adjust to the environment because the subject is able to accept reality and is able to solve every problem faced with good emotional control, confidence, openness in purpose, and responsibility can also establish relationships in amanner quality.

Furthermore, based on the opinions of Runyon and Haber (1984), the characteristics of individuals who can adjust well are five, namely: a) theperception rightof reality, b) the ability to deal with stress and anxiety, c) having a self-image positive, d) ability to express good emotions, e) good interpersonal relationships. One aspect of developing adolescent self-adjustment abilities according to Runyon and Haber (1984) is the ability to deal with stress and anxiety related to problem solving in a person. Adolescents who are in a situation of changingenvironments schoolwill feel tension, anxiety, and conflicts that require them to be able to overcome the problem in order to complete their education.

The results of the research obtained also showed that adolescent adjustment was included in the high category.
The results obtained indicate that the majority of class VII students who enter in early adolescence can make a good adjustment process in their new environment. This is indicated by the ability of students to communicate with friends and teachers in the new environment, can understand the existence of changes in the environment, be able to behave in accordance with the regulations imposed in secondary schools that are clearly different from the environment in elementary schools. This condition turns out to be related to self-concept factors and problem solving.

The results showed the magnitude of the effective contribution of self-concept and problem solving with adolescent adjustment by $40.5 \%$, while the remaining $59.5 \%$ was influenced by other factors not examined. This shows that self-concept and problem solving are factors that significantly influence the ability of self-adjustment and donations given two variables, namely self-concept and problem solving is a high category.

Based on the results of the study also found that the second hypothesis instudy thiswhich reads "there is a relationship between self-concept and self-adjustment" is acceptable. This means that there is a positive and significant relationship between concept and self-selfadjustment. This can be indicated by the ability of adolescents to accept their strengths and weaknesses, so that teens feel comfortable and confident in themselves when interacting with friends and teachers in a new environment, so that they are better able to adjust to new environments.

The results of this study are consistent with the research conducted by Annisa and Handayani (2012) about the relationship between self-concept and emotional maturity with the adjustment of the wife who lives with the husband's family. From the results of the study, it was found that self-concept is positively and very significantly related to adjustment to the wife who lives with the husband's family. This indicates that individuals who have a positive self-concept and have a positive attitude towards everything, reality expectations, believe in the skills and skills they have have an influence on the process of thinking, feeling, desires, values and goals of a person's life so that they have adjustment the good one.

Self-concept is a basic concept of self, thoughts and personal opinions, awareness of what and who he is, and how the comparison between himself and others and how some of the idealism that has been developed. According to Wirawan (in Annisa and Handayani, 2012) self-concept isaspect of a very importantself because one's personality and self-concept will influence the whole action of that person. The concept of self is very closely related to the individual self. Healthy life, both physical and psychological, is supported by a good and stable self-concept.

The results of the study also showed that there was a positive and significant relationship between problem solving and self-adjustment which was the third 
hypothesis instudy this. In line with Sawrey and Telford's opinion (in Wijaya, 2007) whichthat statesindividuals who can adjust themselves are individuals who can interact continuously with their environment which involves a system of behavioral, cognitive and emotional. Whitman (1980) also states that self-adjustment is a developmental process. Development isprocess an ongoingwhere individuals make adjustments to the changing world.

Individuals who make adjustments can be seen from their development, including gene growth, cognitive process growth, language skills, socialization. Individual thinking ability can develop because of interactions with the surrounding environment. The thinking process associated with problem solving can train someone to think critically, logically, creatively that is very necessary in dealing with changes and developments that occur in the community environment (Fauziah, 2010). That is, individuals who develop their thinking skills can be demonstrated by good problem solving are individuals who are able to adjust well too. Adolescents who are able to adapt show a positive attitude when facing discomfort or disparity in the new environment, understanding the subject matter and being able to recognize the potential they have as a source of strength to deal with problems. Able to find alternative solutions and solve problems step by step.

\section{CONCLUSION}

a. Referring to the results of the analysis, the first research hypothesis and said "asignificant relationship between self-concept and problem solving with self-adjustment" was accepted.

b. To the next researcher who is interested in examining the relationship betweenself-development adolescentand the impact on free association at the junior and senior high school level as the formation of adolescent identity this is important to do due to the future of the teenager.

\section{Acknowledgements}

Thank-you note to the faculty of teacher training and education in PGRI Banyuwangi University which has given us the opportunity to serve the nation's development.

\section{REFERENCES}

Ahyani, L. N. \& Kumalasari. F (2012). Hubungan Antara Dukungan Sosial Dengan Penyesuaian Diri Remaja Di Panti Asuhan. Jurnal Penelitian. Kudus: Universitas Muria Kudus.

Ali, M. \& Asrori, M.(2006). Psikologi Remaja, Perkembangan Peserta Didik. Jakarta: Bumi Aksara.

Annisa, N. dan Handayani, A. (2012). Hubungan Antara Konsep Diri dan Kematangan Emosi dengan
Penyesuaian Diri Istri yang Tinggal Bersama Keluarga Suami. Jurnal Psikologi Pitutur. Vol 1, hal. 57- 67.

Azwar, S. (2013). Penyusunan skala psikologi (Ed 2).Yogyakarta: Pustaka Pelajar

Desmita. 2010. Psikologi Perkembangan. Bandung: PT. Remaja Rosdakarya

Fauziah, Anna. 2010. “ Peningkatan Kemampuan Pemahaman dan Pemecahan Masalah Matematika Siswa SMP melalui Strategi React.” Jurnal Forum Pendidikan 30(1).

Fatimah, Enung. (2006). Psikologi Perkembangan. Bandung: Pustaka Setia

Ningrum, Ratna Aditya et al. Pengaruh Kinerja Keuangan, Kepemilikan Institusional Dan Ukuran Dewan Pengawas Syariah Terhadap Pengungkapan Isr. Accounting analysis journal Vol 2 No 4 (2013)

Febrihariyanti, D. N., \& Suharnan. (2013). Pengaruh Pelatihan Dasar Kepemimpinan terhadap Kepercayaan Diri dan Kemampuan Problem Solving Anggota Pramuka. Jurnal Psikologi Indonesia Vol. II , 4-5.

Runyon and Haber (1984) Psychology and Adjusment.Illinoris: The dorsy press

Hurlock, E.B. (1999). Psikologi Perkembangan: Suatu Pendekatan Sepanjang Rentang Kehidupan (edisi kelima). Jakarta: Erlangga.

Maharani \& Andayani (2003). Hubungan Antara Dukungan Sosial Ayah Dengan Penyesuaian Sosial Pada Remaja Laki-laki. Jurnal Psikologi. Yogyakarta: Fakultas UGM.

Monks, C. P., \& Smith, P. K. (2006). Definitions of bullying: Age differences in understanding of the term, and the role of experience. British Journal of Developmental Psychology, 24, 801-821. http://dx .doi.org/10.1348/026151005X82352

Muawanah, Lis Binti, Pratikto Herlan. 2012. Kematangan Emosi, Konsep Diri Dan Kenakalan Remaja. JURNAL PSIKOLOGI VOLUME 7, NO.1, APRIL 2012: 490 - 500

Rakhmat, Jalaludin, 2003. Psikologi Komunikasi, Bandung : PT. Remaja Rosdakarya.

Suharnan. (2005). Psikologi Kognitif. Surabaya: Srikandi.

Suryani et. al. (2016). Psikoedukasi Menurunkan Tingkat Depresi, Stres Dan Kecemasan Pada Pasien Tuberkulosis Paru. Jurnal Ners Vol. 11 No. 1 April 2016: 128-133

Subagyo Pangestu, (2013). Forecasting Konsep dan Aplikasi Edisi Ketiga, Yogyakarta : BPFEYogyakarta.

Worchel, S., Cooper, R., Goethals, G.R, \& Olson, J.M. 2000. Social Psychology. USA: Thomson Learning.

Yuwono, Triwibowo. 2006. Biologi Molekuler. Yogyakarta: Penerbit Erlangga. 
Zebua ,Albertina Saady \& Nurdjayadi, Rosyiana D. 2001.

Hubungan antara konformitas dan konsep diri dengan perilaku konsumtif pada remaja putri. Jurnal Phronesis 3 (6):72-82

Wijaya, Tony.2007. "Kontribusi Rasio Keuangan Terhadap Perubahan Laba Perbankan Di Bursa Efek Surabaya”. Modus, Vol. 19, No. 2

Whitman, R. D. (1980). Recoverability of psychological functioning following alcohol abuse: Lateralization effects. Journal of Consulting and Clinical Psychology, 48(4), 503-510. 